\title{
Political Dialogue between the European Parliament and the Verkhovna Rada of Ukraine (Institutional Capacity, Inter-Parliamentary Communication, New Format of Intercommunication)
}

\author{
Dialog polityczny. Parlament Europejski - Rada Najwyższa Ukrainy \\ (zdolność instytucjonalna, komunikacja międzyparlamentarna, \\ nowy format wzajemnych stosunków)
}

\section{- Abstrakt •}

Artykuł opisuje badania nad współpracą i dialogiem politycznym między Parlamentem Europejskim a Radą Najwyższą Ukrainy. Dialog parlamentarny stanowi jeden z kluczowych elementów systemu polityki zagranicznej. W artykule zawarto tezy, że współpraca z Parlamentem Europejskim przyczyni się do poprawy zdolności instytucjonalnych Rady Najwyższej Ukrainy, jakości procesu legislacyjnego i ustawodawstwa, parlamentaryzmu ukraińskiego, zakresu komunikacji oraz ułatwienia dialogu publicznego. Odnosząc się do najnowszych wydarzeń, wszystko wskazuje na wzmocnienie współpracy pomiędzy władzą ustawodawczą a Unią Europejską oraz przejście na nowy tryb komunikacji pomiędzy tymi stronami.

Słowa kluczowe: Parlament Europejski, Unia Europejska, Rada Najwyższa Ukrainy, dialog parlamentarny, Parlamentarny Komitet Stowarzyszenia, memorandum, rezolucja

\section{- Abstract •}

The article deals with the research of cooperation and political dialogue between the European Parliament and the Verkhovna Rada of Ukraine. Parliamentary dialogue holds one of the key places in the system of foreign policy. The paper determines that cooperation with the European Parliament will contribute to enhancement of the institutional capacity of the Verkhovna Rada, quality of the legislative process and legislation, of Ukrainian parliamentarism, extension of communication, and facilitate interaction with the public. Regarding the latest news, it appears that cooperation with the legislative body of the European Union has strengthened and moved to a new format of intercommunication.

Keywords: European Parliament, European Union, Verkhovna Rada, parliamentary dialogue, Parliamentary Committee of the Association, memorandum, resolution 
Today, the cooperation with the European Union holds one of essential and irreplaceable positions in the system of foreign policy of Ukraine. European integration and membership in the European Union is a strategic priority of state policy. The European choice of Ukraine, which is declared in normative-legal acts, opens new opportunities for cooperation with developed countries of the Union, facilitates realization of national interests, building an economically developed and democratic state, and strengthens inter-parliamentary dialogue and cooperation of parliamentary institutions.

Currently, the development of political dialogue between the European Parliament and the Verkhovna Rada of Ukraine holds one of the key places among the actual problems of the study. In the period of cooperation, legislative bodies of Ukraine and the European Union have built a strong and fruitful relationship that has a positive influence on the situation in the country and implementation of foreign policy. Further parliamentary cooperation should increase the institutional capacity of the Verkhovna Rada of Ukraine and the quality of the legislative process in the country (Lavrova, 2014).

The first legal basis of relations between Ukraine and the European Union was the Partnership and Co-operation Agreement, which initiated the cooperation on a broad range of political, economic, trade and humanitarian issues. It was signed on 16 June 1994 in Luxembourg. The agreement came into force on 1 March 1998 after ratification by all EU members. It created new opportunities for Ukraine to approach the European Union (Uhoda pro partnerstvo..., 1994).

As of today, the Association Agreement is the basic agreement about cooperation between Ukraine and the European Union, which defines strategic goals and format of bilateral relations. This normative act is devised to replace the Partnership and Co-operation Agreement, so it remains the legal basis of relations. The Association Agreement is very important, because it allows moving from partnership and cooperation to political association and economic integration (Uhoda pro partnerstvo..., 1994).

In March 2007, negotiations on a new basic agreement between the EU and Ukraine began.

The signing of the Association Agreement between Ukraine and the EU had two stages. The political part of the Association Agreement as well as the Final Act of the Summit was signed by the Prime Minister of Ukraine Arseniy Yatsenyuk during the extraordinary EU - Ukraine Summit held on 21 March 2014. The economic part of the Association Agreement was signed during the meeting of Ukrainian President Petro Poroshenko with former President of the European Council Herman Van Rompuy, former President of the European Commission 
Jose Manuel Barroso, Heads of State and Heads of Government of the EU Member States on 27 June 2014 in Brussels (Lavrova, 2014).

Finally, long and fruitful hard work had produced a result. On 16 September 2014, there was held the most important event in the history of relations between Ukraine and the European Union. The Verkhovna Rada of Ukraine and the European Parliament ratified the Association Agreement between Ukraine and the EU synchronously. This event is regarded as a symbol of solidarity and importance of Ukraine to the European Union.

It should be mentioned that the Association Agreement with its extent and thematic coverage is the largest international legal document in the history of Ukraine and the largest international agreement with a third country that was ever concluded by the European Union (Uhoda pro asotsiatsiiu..., 2014).

The Agreement adverts to the inter-parliamentary dialogue of the legislative bodies of the European Union and Ukraine, namely the European Parliament and the Verkhovna Rada. The European Parliament is currently one of the main bodies of the European Union, which directly influences decision-making, because it performs a legislative function of the Community together with the Council of the European Union and the European Commission. Since the start of the preparatory stage, the European Parliament openly declared its support for the European aspirations of Ukraine. Synchronous ratification of the Agreement by the legislative bodies of the EU and Ukraine is the key event of the inter-parliamentary dialogue after the Euromaidan (Bezzub, 2015).

The Association Agreement requires creating the Parliamentary Association Committee for effective cooperation and improved dialogue. It was created in accordance with article 467 of the Association Agreement which describes it as a forum for interchange of ideas between members of the Verkhovna Rada of Ukraine and the European Parliament. The Parliamentary Association Committee substitutes Parliamentary Cooperation Committee that functioned within the framework of the Partnership and Co-operation Agreement between Ukraine and the EU.

The main functions of the Parliamentary Association Committee include:

- requesting information about implementation of the Association Agreement from the Association Council;

- providing recommendations to the Association Council;

- creating respective subcommittees;

- awareness of decisions and recommendations of the Association Council (Mizhparlamentsjkyj dialogh...).

Let us consider the basic principles of operation of the Parliamentary Association Committee. The chairmanship in the Parliamentary Association Committee 
is executed in turn by a representative of the Verkhovna Rada of Ukraine and a representative of the European Parliament (Komitet...). The People's Deputy of Ukraine Ostap Semerak was Committee's co-chair from the Verkhovna Rada of Ukraine until April 2016. On 14 April 2016 Ostap Semerak was appointed Minister of Ecology and Natural Resources in the new Cabinet of Ministers by the Verkhovna Rada of Ukraine. A new co-chair of the Parliamentary Association Committee will be elected after all factions present their candidates to replace those who changed their positions.

Iryna Herashchenko, the First Deputy Chairman of the Verkhovna Rada, will temporarily lead the Ukrainian delegation of the Committee. From the European Parliament, the Committee is headed by Andrej Plenković, Deputy from the faction of the European People's Party. The latter, while expressing an opinion on the importance of the created Committee, noted that its creation gives an additional impetus to relations between the European Parliament and the Verkhovna Rada of Ukraine. Both parties should use the opportunities provided by the Association Agreement to extend the parliamentary dimension of relations between Ukraine and the European Union and to make a clear and ambitious work program for implementation of goals (Ukrajinsjka chastyna...).

The main goal of the Parliamentary Association Committee is to actively assist Ukraine in achieving greater development and progress in the process of reforming the necessary areas, which leads to integration into the European Union. One of the main tasks of the Committee is to watch closely the implementation of the Agreement, to provide timely specific and practical recommendations to the Association Council.

Another fact, that confirms commitment and interest of the European Parliament in improvement of the situation in Ukraine and its integration into the EU, is the creation of an informal group "Friends of European Ukraine". The main goal of the group is to supplement the work of the Parliamentary Association Committee and to strengthen unity of the political forces of the European Parliament in supporting Ukraine.

The EURONEST Parliamentary Assembly is responsible for multilateral component of relations between the European Parliament and Ukraine, and other Eastern European partners too (Parlamentsjkyj...).

Ratification of the Association Agreement, creation of the Parliamentary Committee and resolutions adopted by the European Parliament suggest that the European Union is not indifferent to the fate of Ukraine.

Analysis of the last two years of inter-parliamentary dialogue after Euromaidan allows suggesting that the relationship between the legislative institutions has 
strengthened (Khronologhija dvostoronnikh...). This is confirmed by the fact that over this last short period the European Parliament has adopted 10 resolutions, which clearly expresses the solidarity and support of efforts of the Ukrainian people for a free, democratic, independent Ukraine and its European perspective (table 1).

Table1. Resolutions of the European Parliament 2014-2016

\begin{tabular}{|c|c|c|}
\hline 2014 & 2015 & $2016(15.03)$ \\
\hline $\begin{array}{l}\text { 06.02. - Resolution on the } \\
\text { situation in Ukraine, which } \\
\text { condemns the violence and } \\
\text { act of force, calls to settle the } \\
\text { conflict }\end{array}$ & $\begin{array}{l}\text { 15.01. - Resolution on } \\
\text { Ukraine with a call to } \\
\text { strengthen sanctions against } \\
\text { Russia }\end{array}$ & $\begin{array}{l}\text { 21.01. - Resolution on the } \\
\text { Association and agreements as } \\
\text { to comprehensive free trade } \\
\text { with Georgia, Moldova and } \\
\text { Ukraine }\end{array}$ \\
\hline $\begin{array}{l}\text { 27.02. - Resolution on } \\
\text { the situation in Ukraine in } \\
\text { support of the national unity } \\
\text { and territorial integrity }\end{array}$ & $\begin{array}{l}\text { 12.03. - Resolution in } \\
\text { support of the Ukrainian } \\
\text { pilot, People's Deputy of } \\
\text { Ukraine - Nadiya Savchenko }\end{array}$ & $\begin{array}{l}04.02 . \text { - Resolution as to } \\
\text { Crimea, which stated that } \\
\text { Crimea is part of Ukraine, } \\
\text { and crimes committed during } \\
\text { the annexation must be } \\
\text { investigated by the Hague } \\
\text { Tribunal }\end{array}$ \\
\hline $\begin{array}{l}\text { 13.03. - Resolution } \\
\text { in support of the new } \\
\text { Ukrainian government } \\
\text { and condemnation of the } \\
\text { illegal actions of the Russian } \\
\text { Federation regarding the } \\
\text { Crimea }\end{array}$ & $\begin{array}{l}\text { 30.04. - Resolution, which } \\
\text { calls for the immediate release } \\
\text { of Nadiya Savchenko and } \\
\text { other Ukrainian citizens } \\
\text { detained by Russia }\end{array}$ & \\
\hline $\begin{array}{l}\text { 17.04. - Resolution to } \\
\text { support the leadership of } \\
\text { Ukraine in realization of their } \\
\text { right to the renewal of power } \\
\text { and self-defense, warning } \\
\text { Russia against invasion under } \\
\text { the pretext of escalating the } \\
\text { situation }\end{array}$ & $\begin{array}{l}\text { 10.06. - Resolution, which } \\
\text { recognizes that Russia can } \\
\text { no longer be considered } \\
\text { a strategic partner of the } \\
\text { European Union as a result } \\
\text { of their actions in Crimea, in } \\
\text { Eastern Ukraine }\end{array}$ & \\
\hline $\begin{array}{l}\text { 17.07. - Resolution in } \\
\text { support of the peace plan to } \\
\text { resolve the conflict in Ukraine }\end{array}$ & $\begin{array}{l}\text { 10.09. - Resolution in } \\
\text { support of Ukraine and with } \\
\text { demand of Russia to release } \\
\text { Ukrainian prisoners }\end{array}$ & \\
\hline $\begin{array}{l}\text { 18.09. - European Parliament } \\
\text { resolution urging EU to repel } \\
\text { Russia }\end{array}$ & & \\
\hline
\end{tabular}

Source: developed by the Author. 
The European Parliament has taken an uncompromising position on Ukraine. In particular, the EP expresses its strong support to sovereignty and territorial integrity of Ukraine and its European choice, condemns the Russian aggression and illegal annexation of the Crimea. The European Parliament is paying particular attention to the issue of liberation of Ukrainian political prisoners illegally detained in Russia. The European Parliament also repeatedly expressed its support to the European perspective of Ukraine, as well as to introduction of the visa-free regime for the Ukrainian citizens (Parlamentsjkyj...).

These resolutions are adopted by the European Parliament in a difficult and unstable time for Ukraine, which again emphasizes that the Ukrainian issues and problems are among the key priorities of the European Parliament.

The Parliamentary dialogue is also marked by high dynamic at the highest political level. On 11-12 September 2014, President of the European Parliament Martin Schulz paid his first official visit to Ukraine. Therefore, the former Chairman of the Verkhovna Rada of Ukraine Volodymyr Groysman paid an official visit to the European institutions in Brussels on 24 February 2015, and thus initiated the launch of a joint program to improve the institutional capacity of the Verkhovna Rada, to reform it and make more efficient. It became a significant political message of Ukraine's strong commitment to the European integration.

In the context of further strengthening of the parliamentary dialogue, another visit of President Schulz to Ukraine took place on 2-3 July 2015. In the framework of this visit, the Memorandum of Understanding between the European Parliament and Verkhovna Rada of Ukraine on a joint framework for parliamentary support and capacity building was signed by Chairman Groysman and President Schulz. The Memorandum is a unique, historically important and strategic document on cooperation between the two parliaments. It clearly identifies the reform of the Ukrainian Parliament and effective implementation of the Association Agreement (Verkhovna Rada..., 2015).

The purpose of the Memorandum is to make the Verkhovna Rada of Ukraine a strong, effective and independent Parliament that is able to introduce and implement the necessary reforms, and the spread of new political culture, which is so important for the development of civil society in Ukraine.

The main goals of the Memorandum of Understanding between the Verkhovna Rada of Ukraine and the European Parliament are:

- ensuring the effective performance of the constitutional functions of the Verkhovna Rada of Ukraine, namely legislative, controlling and representative;

- improving the quality of Ukrainian parliamentarism; 
- increasing transparency, predictability, efficiency and openness of work of the Verkhovna Rada of Ukraine;

- implementing the Association Agreement between Ukraine and the EU.

In view of the mentioned goals, the main objectives of the document are:

- improving the quality of legislation and legislative process in Ukraine;

- strengthening institutional capacity of parliamentary committees using the best European experience for planning and organization of their work, as well as supporting the political analysis with the aim of harmonization of Ukrainian legislation with EU legislation;

- revision of regulations and other documents that define the internal organization of the Verkhovna Rada of Ukraine, as well as aiding the development of a code of conduct for parliamentarians;

- increasing efficiency of interaction between the majority and the opposition, between the political factions and between committees of the Verkhovna Rada of Ukraine;

- strengthening human resources and reforming the Apparat of Verkhovna Rada of Ukraine into a modern service that focuses on the provision of services;

- improving communication and facilitating the interaction of the Verkhovna Rada of Ukraine with the public, civil society, media and other stakeholders (Memorandum pro vzajemorozuminnja..., 2015).

After the synchronous ratification of the Association Agreement, the Memorandum of Understanding is the next important step on a common path to European unity. The signing of this agreement shows the aspiration of the European Parliament to support Ukraine in reforms and actions.

Another important step in strengthening inter-parliamentary relations was holding the "Ukrainian week" in the European Parliament which was conducted from 29 February to 2 March 2016. This is an exceptional event not only for Ukraine but also for the European Union, which opened its legislative body for representatives of a third country, which needs support in difficult times.

This fact confirmed that the European Parliament, despite the wide spectrum of political forces in its structure and ambiguous attitude to Ukraine, is a proUkrainian European institution (Jaroshevych, 2016).

During the "Ukrainian week", European and Ukrainian experts, the deputies held a series of discussions, conferences and specialized sessions. All these measures aimed to identify the main problems in the functioning of the Verkhovna Rada of Ukraine and the reforms in order to improve the situation of the state, to establish cooperation and interaction of the Parliament with the citizens and the 
government. An important argument for closer cooperation between the legislative institutions is that this event coincided with the publication of the Report and Roadmap on Internal Reform and Capacity-Building for the Verkhovna Rada of Ukraine and the signing of the Administrative Cooperation Agreement between the secretariats of the two parliaments.

We can say that the signed document has no historical analogues and is a completely new form of cooperation between the European Parliament and the Verkhovna Rada of Ukraine. The Agreement was the result of work of European Parliament's Needs Assessment Mission in the framework of the Memorandum of Understanding between the European Parliament and the Verkhovna Rada. The objective of the mission led by former European Parliament President Pat Cox is to develop recommendations for a program of parliamentary support and enhance the institutional capacity of the Ukrainian Parliament.

Recommendations of the European Parliament, which are set out in the Report and Roadmap on Internal Reform and Capacity-Building for the Verkhovna Rada of Ukraine concern primarily: legislative ability and legislative process in the Verkhovna Rada of Ukraine; political oversight of the executive branch of government; openness, transparency and accountability to the citizens; harmonization of Ukrainian legislation with EU law; administrative capability; coalition, opposition and dialogue in the Verkhovna Rada of Ukraine; observance of ethical standards and standards of conduct (Dopovidj ta dorozhnja karta...).

To summarize, it can be argued that the European experience of parliamentarism, development of cooperation between the legislative institutions of the European Parliament and the Verkhovna Rada of Ukraine is certainly a valuable landmark for our state because its further development is impossible without effective and strong institutions, systems, technical and human resources, in the first place. Thanks to the European experience, inter-parliamentary dialogue and reform, the Verkhovna Rada of Ukraine should become the basis of democracy and authority, which will start the upgrading of the institutional system of our country. It should be noted that it is the fateful implementation of reforms in the country depends on internal reform of the Parliament of Ukraine. The main objective of the reform of the Verkhovna Rada of Ukraine is to consolidate all efforts into making important and quality laws for the country and to unite the efforts for the European future.

The last two years have been full of wonderful events that testify to the involvement of the European Union in the fate of Ukraine. In particular, the resolutions of the European Parliament adopted lately, the signed documents, the synchronous ratification of the Association Agreement, the establishment of the 
Parliamentary Association Committee, the signing of a Memorandum of Understanding, Administrative Cooperation Agreement, development of recommendations for improving the institutional capacity of the Ukrainian Parliament, which are set out in the Roadmap on Reform for the Legislative Body of Ukraine, numerous official visits at the highest level and other events emphasize support for the territorial integrity and independence of Ukraine from the European parties, importance of political consolidation and national unity for further progress of Ukrainian interests in the European Union. It also confirms that the European Parliament does not stay away from solving problems in Ukraine and becomes a party to settlement process of the conflict caused by the Russian aggression.

It can be argued that during the last period, the relations between the European Parliament and the Verkhovna Rada became stronger and more efficient than ever.

\section{References:}

Dopovidj ta dorozhnja karta shhodo vnutrishnjoji reformy ta pidvyshhennja instytucijnoji spromozhnosti Verkhovnoji Rady Ukrajiny. (2016). Derived from: http://www.europarl. europa.eu/resources/library/media/20160301RES16508/20160301RES16508.pdf.

Jaroshevych, M. (2016). Ukrajinsjkyj tyzhdenj v Jevroparlamenti: integhracijnyj postup chyshyrokyj zhestj evropejciv. www.business.ua. Derived from: http://www.business.ua/ opinions/ukra_nskiy_tizhden_v_vroparlament_ntegrats_yniy_postup_chi_shirokiy_ zhest_vropeyts_v-282048/.

Khronologhija dvostoronnikh vidnosyn. Derived from: http://eeas.europa.eu/delegations/ ukraine/eu_ukraine/chronology/index_uk.htm.

Komitet asociaciji. Derived from: http://ukraine-eu.mfa.gov.ua/ua/ukraine-eu/dialogue/ committee.

Lavrova, I. (2014). Stanovlennia vidnosyn mizh Ukrainoiu ta Yevropeiskym Soiuzom: vid istorychnykh umov do sohodennia. Eminak: naukovyi shchokvartalnyk, 1-2, 46-52.

Memorandum pro vzajemorozuminnja mizh Verkhovnoju Radoju Ukrajiny ta Jevropejsjkym Parlamentom pro spiljni ramky parlamentsjkoji pidtrymky ta pidvyshhennja instytucijnoji spromozhnosti. (2015). Derived from: http://zakon0.rada.gov.ua/laws/show/n000200115.

Mizhparlamentsjkyj dialogh Ukrajina-Jevropejsjkyj Sojuz. Derived from: http://mfa.gov.ua/ ua/about-ukraine/european-integration/inter-parliamentary-dialogue.

Parlamentsjkyj dialogh. Derived from: http://ukraine-eu.mfa.gov.ua/ua/ukraine-eu/parliamentary.

Uhoda pro asotsiatsiiu mizh Ukrainoiu, z odniiei storony, ta Yevropeiskym Soiuzom, Yevropeiskym spivtovarystvom $z$ atomnoienerhii i yikhnimy derzhavamy-chlenamy, $z$ inshoi storony. (2014). Derived from: http://zakon3.rada.gov.ua/laws/show/984_011. 
Ukrajinsjka chastyna Parlamentsjkogho komitetu asociaciji. Derived from: http://w1.c1.rada. gov.ua/pls/mpz/organizations.perm_delegation?delegation $=76$.

Verkhovna Rada i Jevroparlament pidpysaly Memorandum pro vzajemorozuminnja. (2015). Derived from: http://ipress.ua/news/rada_i_yevroparlament_pidpysaly_memorandum_ pro_vzaiemorozuminnya_130305.html. 